\title{
The Blockade of IL6 Counterparts the Osmolar Stress-Induced Apoptosis in Human Conjunctival Epithelial Cells
}

\author{
Hee-Jung Ju, ${ }^{1}$ Yong-Soo Byun, ${ }^{1,2}$ Jee-Won Mok, ${ }^{1}$ and Choun-Ki Joo ${ }^{1,2}$ \\ ${ }^{1}$ Catholic Institute for Visual Science, Seoul St. Mary's Hospital, Seoul 06591, Republic of Korea \\ ${ }^{2}$ Department of Ophthalmology, Seoul St. Mary's Hospital, College of Medicine, The Catholic University of Korea, \\ Seoul 06591, Republic of Korea \\ Correspondence should be addressed to Choun-Ki Joo; ckjoo@catholic.ac.kr
}

Received 12 January 2016; Accepted 4 May 2016

Academic Editor: Edit Tóth-Molnár

Copyright (C) 2016 Hee-Jung Ju et al. This is an open access article distributed under the Creative Commons Attribution License, which permits unrestricted use, distribution, and reproduction in any medium, provided the original work is properly cited.

\begin{abstract}
To determine the effect of hyperosmolarity on cell survival/apoptosis of conjunctival epithelial cells and evaluate the possible role of IL6, Wong-Kilbourne derivative of Chang conjunctival cell line (WKD) was used in this study. Confluent cells were incubated under different osmolarity ( $290 \mathrm{mOsm}$ and $500 \mathrm{mOsm})$ with or without neutralizing IL6 antibody $(50 \mathrm{ng} / \mathrm{mL})$. The expression of IL6 level was measured in the supernatant of each conditioned medium. Cell viability/apoptosis assay was performed using Annexin V/Propidium Iodide (PI) and Cell Counting Kit-8 (CCK-8). Western blot was conducted to measure the abundance of apoptotic markers and IL6 related downstream signaling pathway. The concentration of IL6 showed time-dependent increase in cells treated with $500 \mathrm{mOsm}$. Although apoptosis of WKD cell is increased in treated $500 \mathrm{mOsm}$ for $24 \mathrm{~h}$, apoptosis reduced in WKD cell treated $500 \mathrm{mOsm}$ with anti-IL6 for $24 \mathrm{~h}$. Anti-IL6 inhibited the activation of JAK-STAT signaling pathway, which was induced by hyperosmolarity. Hyperosmolar condition induced apoptosis in conjunctival epithelial cells, along with increase of IL6 production. IL6 neutralizing antibody inhibited apoptosis and JAK-STAT signaling in hyperosmolar condition. These findings suggested that IL6 may be involved in apoptotic change and in hyperosmolarity.
\end{abstract}

\section{Introduction}

Dry eye syndrome is a multifactorial disease, which is caused by a vicious cycle: abnormalities of tear film and lacrimal hyposecretion induce the break-up of tear film, and the following inflammation of ocular surface deteriorates the secretion and the composition of tears [1]. Hyperosmolarity is induced by lacrimal hyposecretion or the increase of evaporation evokes desquamation, decreased intercellular connections, blunting and loss of microplicae, cell membrane disruption, and cellular swelling with decreased cytoplasmic density in the corneal epithelium [2]. Moreover, hyperosmolarity provokes squamous metaplasia, loss of goblet cells, and inflammation in the conjunctival epithelium [3-5]. These phenomena decrease the production of mucin for lubricating corneal epithelium, and the reduction of mucin aggravates dry eye [6]. Histologic findings of dry eye in patients with Sjögren syndrome and immunosuppressant patients, such as postbone marrow transplantation state, were reported as a reduction of goblet cells, increment of inflammatory cells in cornea and conjunctiva, and inflammation with fibrosis of the lacrimal gland [7-10]. Dry eye also induces the secretion of cytokines such as IL6, IL-1 $\beta$, TNF- $\alpha$, and IFN- $\gamma$ [11]. Cyclosporin, one of the drugs suppressing those cytokines, reduces the infiltration of conjunctival cells and IL6, regulates the necrosis of conjunctival epithelial cells, and elevates the number of goblet cells by preventing the loss of the cells [12].

IL6 has been known as a representative cytokine with increased expression in tears and the conjunctival epithelium of eyes with dry eye syndrome. It has also been reported to have pro- and anti-inflammatory effects. As evidence of the proinflammatory effects, a report revealed that IL6 treatment reduced the survival of liver cancer cells [13] and tocilizumab, an IL6 blocker, has been used as a therapeutic drug for autoimmune diseases in rheumatology. Anti-inflammatory effects of IL6 were revealed by the following evidence: IL6 
treatment on cells increased migration [14], IL6 induced cell migration and wound healing of mouse biliary epithelial cells [15], blocking of IL6 reduced inflammatory-related molecules in mouse alkali burn model [16], and IL6-deficient mice showed delayed wound healing after skin resection [17].

Although IL6 has been well known as an important cytokine on disease progression and severity associated with immune mechanisms, its role in dry eye was still vague except for increased expression on the ocular surface. Therefore, this research investigated the role of IL6 on apoptosis of conjunctival epithelial cells after hyperosmolarity.

\section{Material and Methods}

2.1. In Vitro Osmolar Stress Experiment. The WongKilbourne derivative of Chang conjunctival cells (WKD, ATCC CCL-20, Manassas, VA, USA) were cultured in Dulbecco's modified Eagle's Medium F12 (1:3) culture medium (Invitrogen, Waltham, MA, USA), supplemented with $1 \%$ penicillin and streptomycin (WELGENE, Daegu, Seoul) and 5\% heat-inactivated fetal bovine serum (WISENT, Quebec, Canada). When cells were approximately 80-90\% confluence, culture medium was replaced with fresh medium with added $1 \mathrm{M} \mathrm{NaCl}$ to increase the osmolarity (corresponding to $290,500 \mathrm{mOsm}$ ) for $24 \mathrm{~h}$. Cells were incubated for $24 \mathrm{~h}$ before protein extraction and conditioned medium collection.

The blockade of IL6 was done $24 \mathrm{~h}$ before incubation using the neutralizing Anti-Human IL6 antibody (anti-IL6, Clone 1936, R\&D systems, Minneapolis, MN, USA) for neutralizing the IL6. To determine whether IL6 cytokine has protected effect in the $\mathrm{NaCl}$ exposure or not, conjunctiva epithelial cells were incubated with IL6 for $24 \mathrm{~h}$ and then exposed to $500 \mathrm{mOsm} \mathrm{NaCl}$ for $24 \mathrm{~h}$.

2.2. Measurement of Cytokine Production. Cell supernatant was collected $290 \mathrm{mOsm}, 500 \mathrm{mOsm} \mathrm{NaCl}$ incubation after $24 \mathrm{~h}$, and then centrifuged $12,000 \mathrm{rpm}$ for $3 \mathrm{~min}$ at $4^{\circ} \mathrm{C}$. Cytokine levels in supernatant were determined using the Human IL-1 $\beta$, IL6, TNF- $\alpha$, and IFN- $\gamma$ Quantikine EnzymeLinked Immunosorbent Assay Kit (R\&D systems, Minneapolis, MN, USA) and we followed the manufacturer's protocol. Briefly, for IL6 kit $100 \mu \mathrm{L}$ of standard and samples were incubated in antibody-coated plate at $2 \mathrm{hrs}$. After being washed four times, add $200 \mu \mathrm{L}$ conjugate solution being incubated at $2 \mathrm{hrs}$. After being washed four times, add $200 \mu \mathrm{L}$ substrate solution being incubated at $20 \mathrm{~min}$. Add $50 \mu \mathrm{L}$ stop solution and read at $450 \mathrm{~nm}$ with reader within $30 \mathrm{~min}$.

2.3. Cell Viability Assay. Cell viability was determined using the Cell Counting Kit-8 (Dojindo, Kumamoto, Japan) according to the manufacturer's instructions. Cells $\left(1 \times 10^{5}\right.$ cells $/ \mathrm{mL}$, $100 \mu \mathrm{L})$ were seeded in 96-well plate. When cells were confluent $80 \%-90 \%$, cells were treated with anti-IL6 for $24 \mathrm{~h}$. After treatment for $24 \mathrm{~h}$, add $10 \mu \mathrm{L}$ of CCK-8 solution and incubate the plate for $1 \mathrm{~h}$ and cover the plate to protect from light, and then measure the absorbance using a microplate reader at $450 \mathrm{~nm}$. The experiment was performed three times.
2.4. Flow Cytometry. Cells were seeded at $1.5 \times 10^{6}$ cells in a well of $60 \mathrm{~mm}$ plates and cultured until confluent 80-90\%. Cells were exposed to $290 \mathrm{mOsm}, 500 \mathrm{mOsm}$ $\mathrm{NaCl}$ with/without anti-IL6 $50 \mathrm{ng}$ for $24 \mathrm{~h}$. After $24 \mathrm{~h}$, cells were collected and resuspended. For labeling the Annexin V/Propidium Iodide (PI), we were using the Annexin V/PI kit (Invitrogen, Eugene, Oregon, USA). The suspension cells were labeled with Annexin V/PI and analyzed by flow cytometry (BD, Franklin, New Jersey).

2.5. Western Blot Assay. Cells were harvested by scraping with RIPA buffer. Extracts were incubated for $2 \mathrm{~h}$ at $4^{\circ} \mathrm{C}$ and obtained by centrifugation $(13,000 \mathrm{rpm}$ for $20 \mathrm{~min}$ at $4^{\circ} \mathrm{C}$ ). Protein concentrations were determined using the BCA assay Kit (Thermostat, Hercules, CA, USA), and wholecell extracts were adjusted to same amount of total protein $(20 \mu \mathrm{g})$. Samples were electrophoresed in 10\% SDS-PAGE. Proteins were then transferred onto a PVDF membrane (Millipore Corporation, Billerica, MA, USA) at $300 \mathrm{~mA}$ for $90 \mathrm{~min}$ at $4^{\circ} \mathrm{C}$, and the membranes were incubated with $3 \%$ BSA (Sigma-Aldrich, St. Louis, MO, USA) in TBST to block nonspecific binding. Primary antibodies were incubated over night at $4^{\circ} \mathrm{C}$. And we washed five times with TBST $(0.5 \%$ tween 20 in $1 \mathrm{x}$ TBS) the secondary antibodies conjugated horseradish peroxidase (HRP) (Santa Cruz, Dallas, Texas, USA) that was applied and incubated for $1 \mathrm{~h}$ at RT. After five times of washing with TBST (0.5\% tween 20 in $1 x$ TBS), the membrane followed by chemiluminescent detection using Immobilon Western Substrate (Millipore Corporation, Billerica, MA, USA) with the ChemiDoc MP Imaging system (Bio-Rad Laboratories Inc., Hercules, California, USA). The antibodies diluents were shown at Table 1.

2.6. Statistical Analysis. All results were indicated as means \pm SEM. The results were analyzed by Kruskal-Wallis analysis, followed by a Mann-Whitney analysis. A $p$ value of less than 0.05 was considered to be statistically significant.

\section{Results}

3.1. Hyperosmolarity Induces IL6 Levels in the WKD Cells. WKD cells were cultured under $290 \mathrm{mOsm}$ and $500 \mathrm{mOsm}$ for $24 \mathrm{~h}$ and the cell viability was analyzed. There were no definite apoptotic cell deaths in $290 \mathrm{mOsm}$, while cell viability was significantly reduced after $12 \mathrm{~h}$ in $500 \mathrm{mOsm}(0.95 \pm 0.04$ at $12 \mathrm{~h}, 0.69 \pm 0.012$ at $24 \mathrm{~h}$, and $0.47 \pm 0.12$ at $48 \mathrm{~h}$, resp., $p=$ 0.05 at $12 \mathrm{~h}, 24 \mathrm{~h}$ ) (Figure 1(a)). We assessed the levels of IL-1 $\beta$, TNF- $\alpha$, IFN- $\gamma$, and IL6 from medium of cells cultured under $290 \mathrm{mOsm}$ and $500 \mathrm{mOsm}$ to identify the inflammatory cytokines which are well known to increase in epithelial cells by hyperosmolarity stress. Quantitative analysis showed that, whereas IL-1 $\beta(0.07 \pm 0.002$ in $290 \mathrm{mOsm}, 0.06 \pm 0.002$ in $500 \mathrm{mOsm}), \mathrm{TNF}-\alpha(0.08 \pm 0.004$ in $290 \mathrm{mOsm}, 0.08 \pm$ 0.0004 in $500 \mathrm{mOsm})$, and IFN $-\gamma(0.08 \pm 0.009$ in $290 \mathrm{mOsm}$, $0.08 \pm 0.003$ in $500 \mathrm{mOsm})$ showed no significant change, IL6 $(1.47 \pm 0.44$ in $290 \mathrm{mOsm}, 3.23 \pm 0.12$ in $500 \mathrm{mOsm})$ were increased $(p=0.05$, Figure $1(b))$. When measuring the time-dependent expression of IL6 in $290 \mathrm{mOsm}$ and $500 \mathrm{mOsm}$, the expression of IL6 in $500 \mathrm{mOsm}$ increased 
TABLE 1: List of antibodies, sources, and dilutions.

\begin{tabular}{lcccc}
\hline & Primary antibody & Host & Dilution & Manufacturer \\
\hline & p-STAT3 & Mouse & $1: 1000$ & Santa Cruz \\
& STAT3 & Rabbit & $1: 1000$ & Santa Cruz \\
JAK-STAT signaling markers & p-ERK1/2 & Rabbit & $1: 1000$ & Santa Cruz \\
& ERK1/2 & Mouse & $1: 1000$ & Santa Cruz \\
& p-mTOR & Rabbit & $1: 1000$ & Santa Cruz \\
& mTOR & Goat & $1: 1000$ & Santa Cruz \\
\hline \multirow{2}{*}{ Apoptosis markers } & Bax & Rabbit & $1: 500$ & Santa Cruz \\
& Bcl2 & Mouse & $1: 500$ & $1: 500$ \\
Housekeeping gene marker & Cleaved caspase-3 & Rabbit & $1: 1000$ & Abcam \\
\hline
\end{tabular}

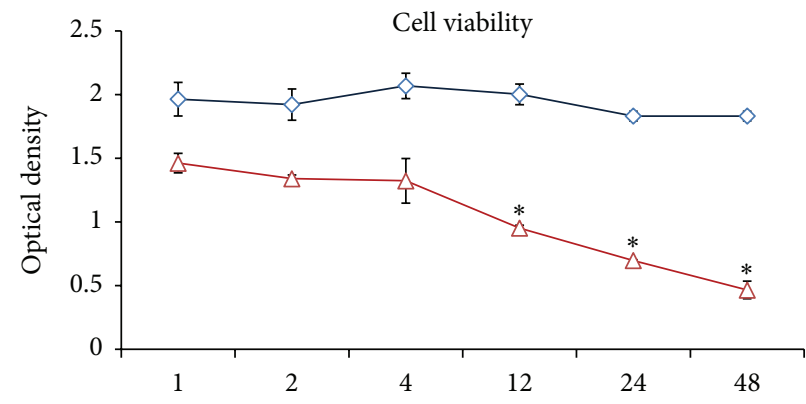

(h)

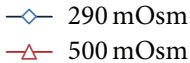

(a)

Cytokine expression

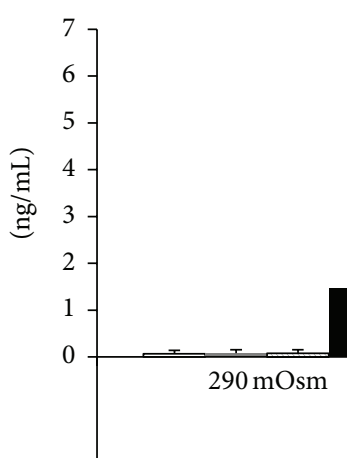

$\square$ IL1 $\square$ IFN- $\gamma$

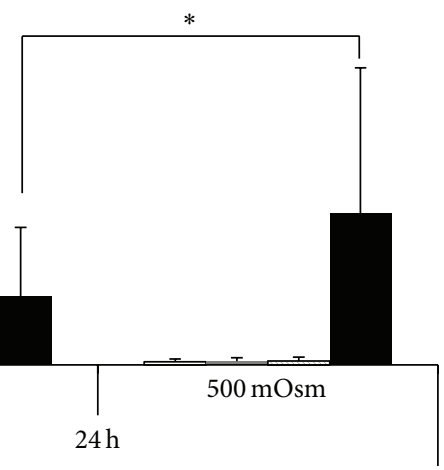

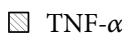

- IL6

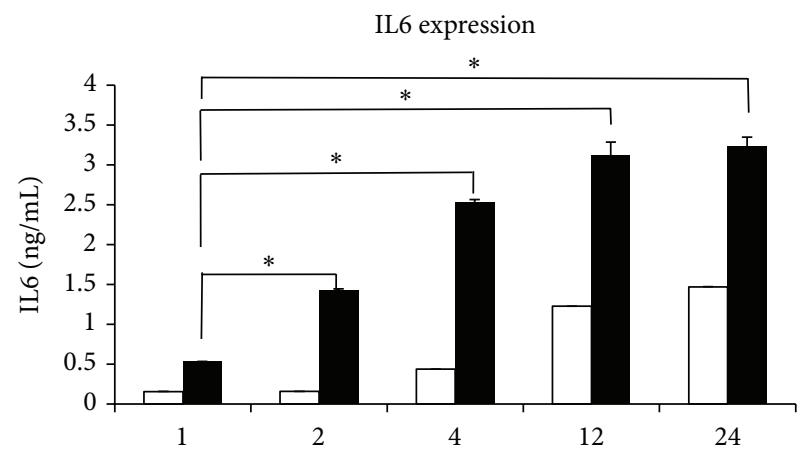

(h)

(b)

(c)

FIGURE 1: Change of conjunctival epithelial cells under $290 \mathrm{mOsm}$ and $500 \mathrm{mOsm}$ conditions. (a) Cell viability was significantly decreased in $500 \mathrm{mOsm}$ at 12, 24, $48 \mathrm{~h}$ compared to $290 \mathrm{mOsm}$. (b) Cytokine ELISA assay showed $500 \mathrm{mOsm}$ was significantly increased compared to 290 mOsm in cell supernatant. (c) IL6 increased depending on the time course, and the expression was higher in $500 \mathrm{mOsm}$ than that in 290 mOsm. ${ }^{*} p=0.05, n=3$.

from $0.012 \mathrm{pg} / \mathrm{mL}$ at $1 \mathrm{~h}$ to $2.1 \mathrm{pg} / \mathrm{mL}$ at $24 \mathrm{~h}$, which was higher than that in $290 \mathrm{mOsm}(p=0.05$, Figure $1(\mathrm{c}))$.

\subsection{IL6 Mediates Hyperosmolarity Induced Apoptotic Cell} Death. To evaluate whether IL6 was secreted to protect cells or induce cell death in apoptosis by hyperosmolarity, $50 \mathrm{ng}$ of anti-IL6 was used for blocking IL6. When investigating change of morphology and cell distributions in $290 \mathrm{mOsm}, 500 \mathrm{mOsm}$, and $500 \mathrm{mOsm}$ with anti-IL6, the cells in $500 \mathrm{mOsm}$ showed shrinkage and more apoptosis 

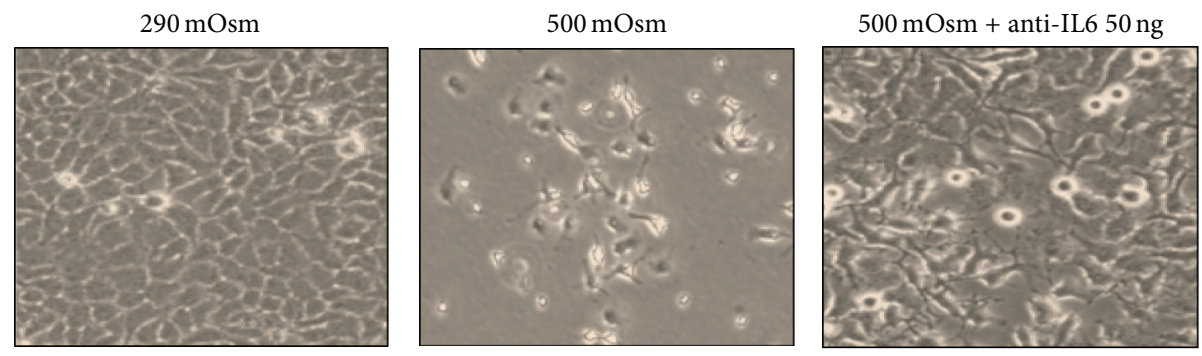

(a)

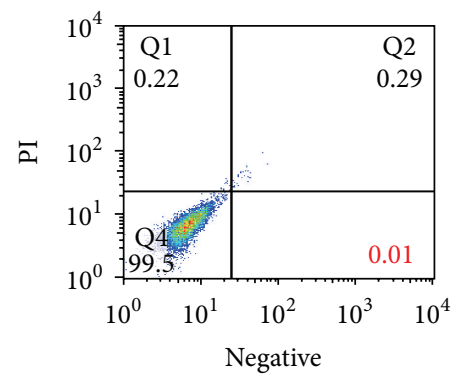

Annexin V

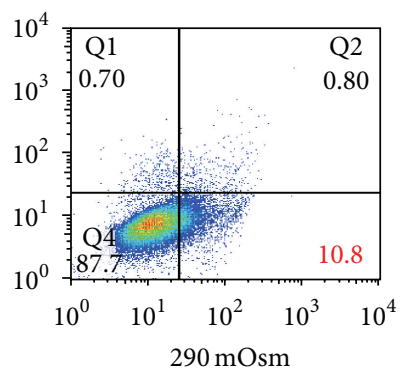

Annexin V

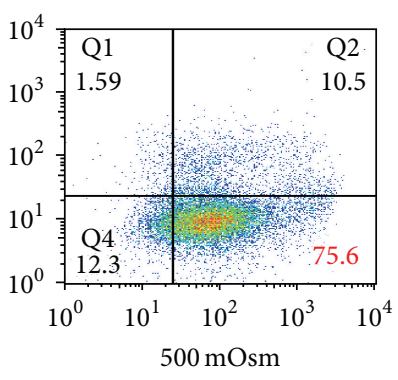

Annexin V

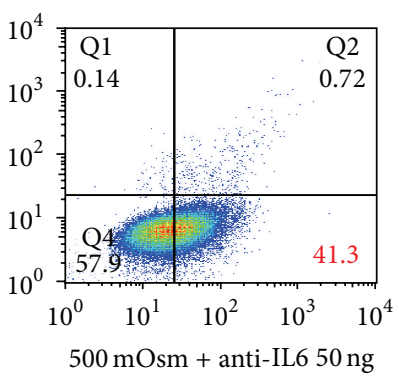

Annexin V

(b)

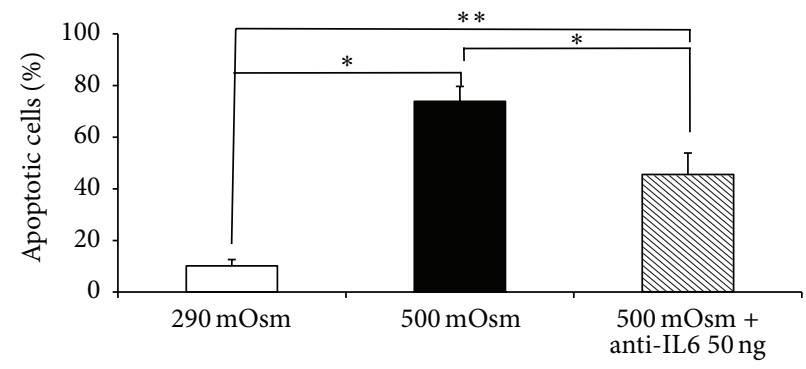

(c)

FIGURE 2: Effect of neutralizing IL6 antibody on cell apoptosis. (a) When evaluating the cell morphology, cell death decreased in $500 \mathrm{mOsm}$ with anti-IL6 treatment. (b) Flow cytometry with Annexin V/PI showed reduced apoptosis under treatment of anti-IL6 and (c) the proportion of apoptotic cells significantly reduced by treatment of anti-IL6. ${ }^{*} p=0.022,{ }^{* *} p=0.023, n=3$.

than in 290 mOsm. Nevertheless, cells in 500 mOsm with anti-IL6 showed less apoptosis and shrinkage than those in 500 mOsm without anti-IL6 (Figure 2(a)).

We have given a $500 \mathrm{mOsm}$ on the conjunctival epithelial cells and the effect of IL6 was examined using Annexin V/PI. The amount of the cells was significantly increased in the cell pretreated with the anti-IL6. The apoptosis rates are increased from $10.2 \pm 2.44$ in $290 \mathrm{mOsm}$ to $73.88 \pm 5.84$ in $500 \mathrm{mOsm}$ and $45.58 \pm 2.89$ in $500 \mathrm{mOsm} \mathrm{NaCl}$ with anti-IL6. Treated anti-IL6 was very effectively decreased for the apoptosis rates in $500 \mathrm{mOsm} \mathrm{NaCl}$ treated (Figure 2(b)).

There was significant difference in the proportions of apoptotic cells among $290 \mathrm{mOsm}, 500 \mathrm{mOsm}$, and 500 mOsm with anti-IL6 (Figure 2(c)), which implies that IL6 could promote apoptosis by hyperosmolarity.

3.3. Anti-IL6 Inhibits JAK-STAT Pathway Activation in Hyperosmolarity Induced Cell Apoptosis. Evaluating JAKSTAT signaling and apoptosis markers by Western blot, the expressions of p-STAT3, p-ERK1/2, and p-mTOR were higher in $500 \mathrm{mOsm}$ (resp., $1.01 \pm 1.16,1.19 \pm 0.22$, and $1.15 \pm 0.08$ ) than $290 \mathrm{mOsm}$ (resp., $0.43 \pm 0.15,0.44 \pm 0.08$, and $0.48 \pm 0.03$ ); however, those were lower in $500 \mathrm{mOsm}$ with anti-IL6 (resp., $0.6 \pm 0.17,0.72 \pm 0.17$, and $0.9 \pm 0.12$ ) than in $500 \mathrm{mOsm}$.

Bax and cleaved-caspase-3 showed higher expression in $500 \mathrm{mOsm}$ (resp., $1.39 \pm 0.37,1.08 \pm 0.02$ ) than in $290 \mathrm{mOsm}$ (resp., $0.37 \pm 0.17,0.49 \pm 0.14$ ), and those were also lower in $500 \mathrm{mOsm}$ with anti-IL6 (resp., $0.7 \pm 0.2,0.68 \pm 0.18$ ) than in $500 \mathrm{mOsm}$. Bcl 2 showed lowest expression in $500 \mathrm{mOsm}$ $(0.3 \pm 0.14)$, followed by that in $500 \mathrm{mOsm}$ with anti-IL6 $(0.66 \pm 0.08)$ and $290 \mathrm{mOsm}(1.24 \pm 0.3)$ (Figure 3(a)). The significant difference of expressions of p-STAT3/total STAT3, p-ERK/total ERK, and p-mTOR/total mTOR was revealed between those in $500 \mathrm{mOsm}$ and $500 \mathrm{mOsm}$ with anti-IL6 $(p=0.05)$ Apoptosis markers such as Bax, Bcl2, and cleaved caspase-3/caspase-3 showed significant discrepancy between those in $500 \mathrm{mOsm}$ and $500 \mathrm{mOsm}$ with anti-IL6 ( $p=0.05$, Figure 3(b)). 


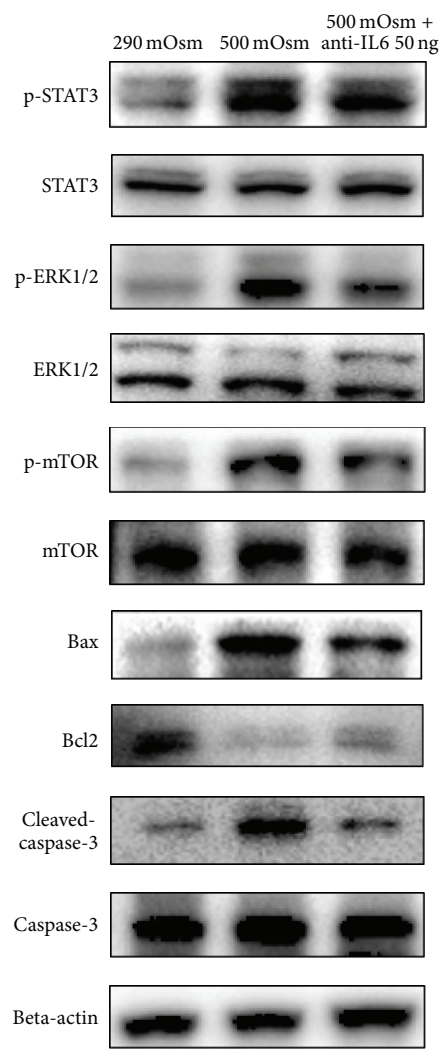

(a)
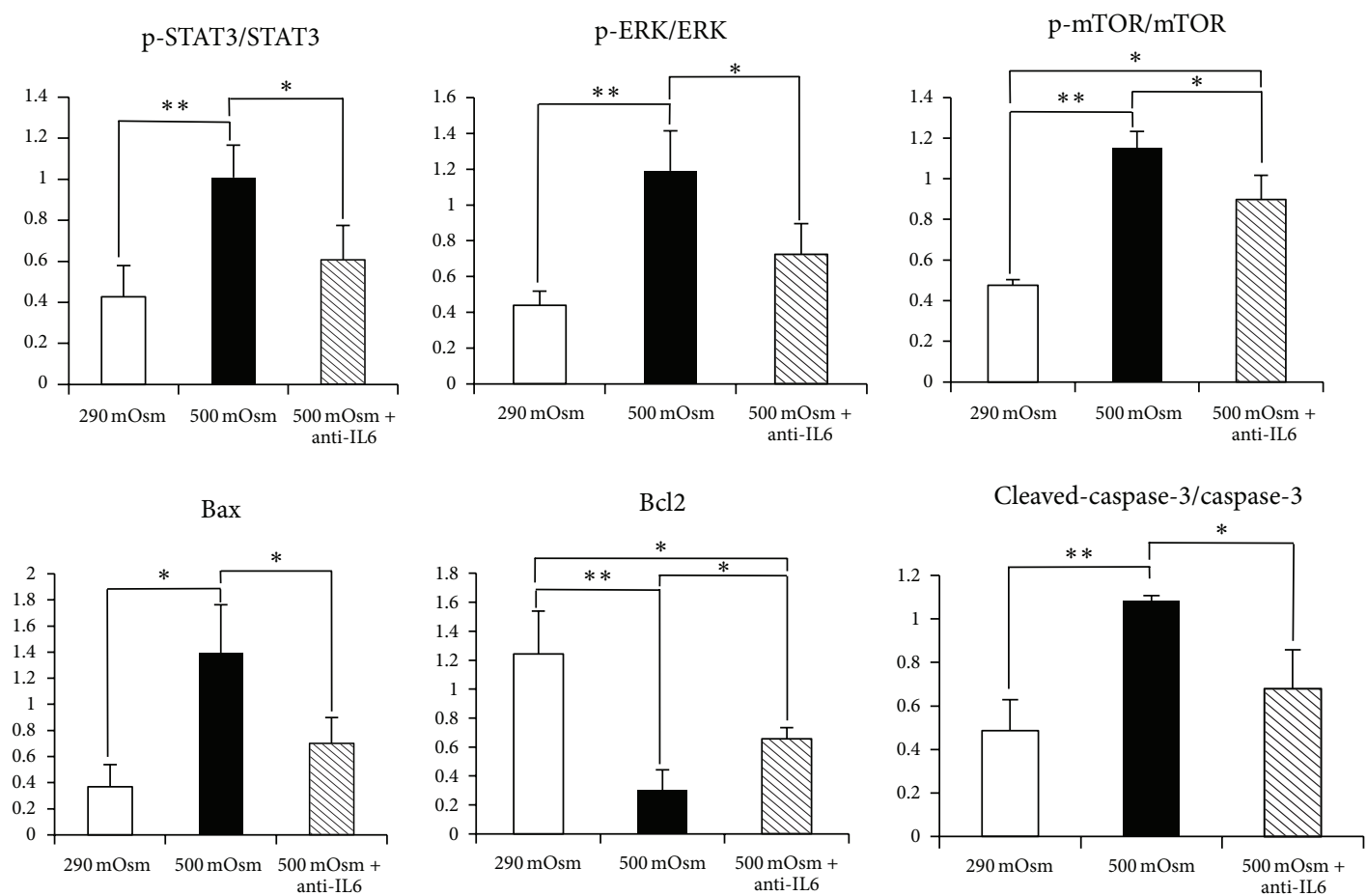

(b)

FIGURE 3: Effect of IL6 on JAK-STAT signaling and apoptosis markers. (a) The factors of the JAK-STAT signaling pathway and apoptosis markers in $500 \mathrm{mOsm}$ and $500 \mathrm{mOsm}$ with anti-IL6 were investigated by Western blot. JAK-STAT signaling was augmented in $500 \mathrm{mOsm}$ and reduced in $500 \mathrm{mOsm}$ with anti-IL6, and apoptosis markers also changed in similar pattern. (b) Those differences between $500 \mathrm{mOsm}$ and $500 \mathrm{mOsm}$ with anti-IL6 were statistically significant in the graph. ${ }^{*} p=0.05,{ }^{* *} p=0.05, n=3$. 


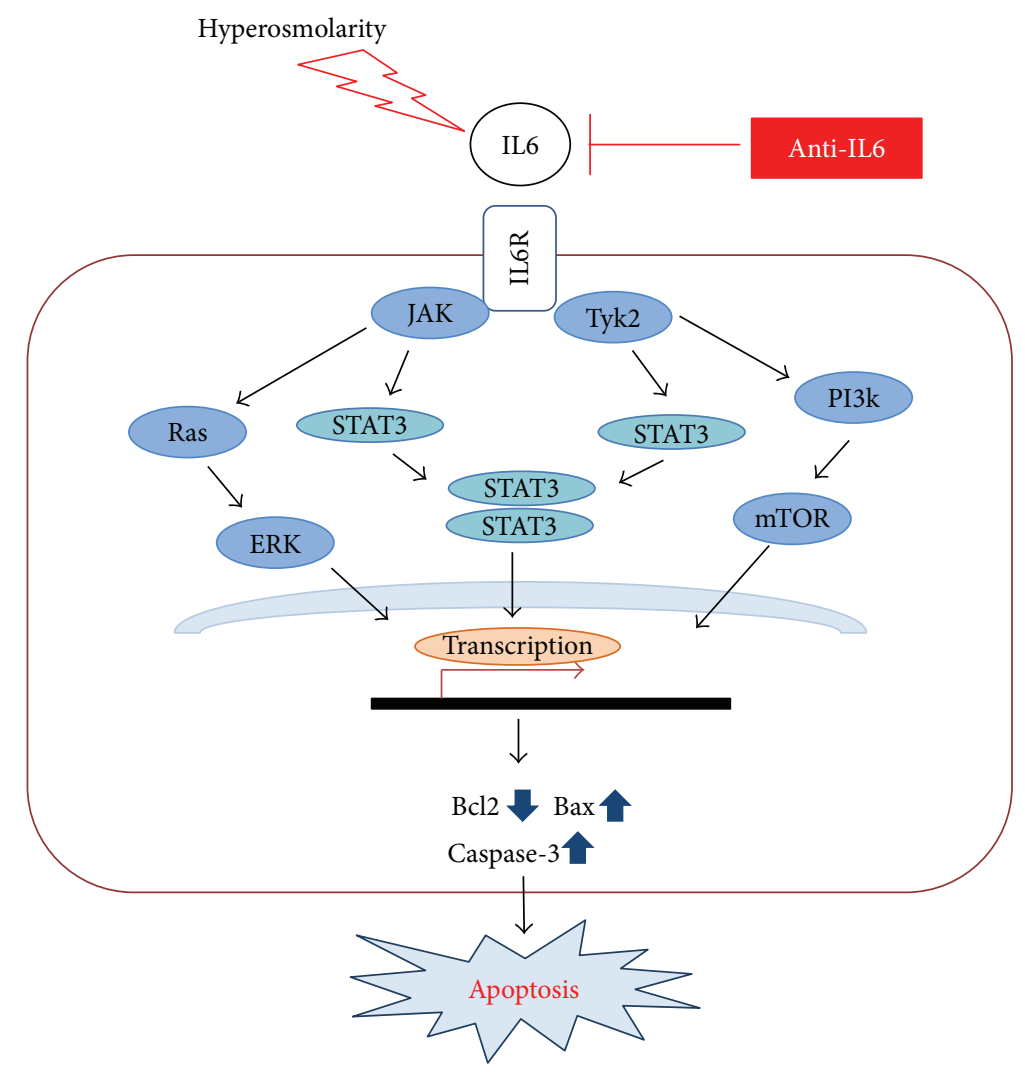

FIGURE 4: The role of IL6 induced by hyperosmolarity. Hyperosmolarity induced the expression of IL6 followed by apoptosis, whereas blocking IL6 suppressed JAK-STAT signaling and apoptosis.

\section{Discussion}

It has been reported that hyperosmolarity stress could induce apoptosis and promote the secretion of diverse proinflammatory cytokines [18]. The association between conjunctival epithelial cells and IL6 has been described in many studies: increased expression of IL- $1 \beta$, IL8, IL6, and TNF- $\alpha$ in conjunctival epithelial cells and tear fluid in the patients with dry eye syndrome $[19,20]$ and increase of IL-1 $\beta$, IL8, and, especially, IL6 in impression cytology $[21,22]$. Those studies suggested conjunctiva epithelial cells could aggravate dry eye and IL6 had an important role in pathomechanism of dry eye. A previous study showed that blocking IL6 could increase goblet cells in conjunctival epithelium and reduce inflammatory cells, which could soothe the symptoms and prevent the chronic progression of dry eye [12]. Flow cytometry analysis showed that the blocking of IL6 significantly suppressed apoptosis observed at $500 \mathrm{mOsm}$, which suggests blocking IL6 could modify apoptosis following hyperosmolarity.

Cytokines such as IL6 can activate the JAK-STAT signaling pathway [23]. IL6 can be activated though the membranebound IL6 receptor (classical pathway) or the soluble type of IL6 receptor (trans-signaling). The IL6 attached with receptor could initiate cascade via JAK activation, and activated JAK kinase phosphorylate induces forming of dimer by phosphorylation of STAT3 $[24,25]$. This signaling pathway promotes proliferation, differentiation, migration, and apoptosis of cells [26]. Although the activation of the JAK-STAT signal by IL6 was observed in cancer [27], there have been few studies for the association between conjunctival epithelial cells and IL6, especially about the role of increased IL6 in a hyperosmolar state of conjunctival epithelial cells. This research revealed that the IL6/JAK/STAT signaling pathway was associated with apoptosis induced by hyperosmolarity. Western blot showed that $500 \mathrm{mOsm}$ promoted the expression of STAT3 (direct signal), ERK, and mTOR (indirect signal), and IL6 reduced the increased expressions. Bax and caspase- 3 as apoptosis markers showed higher expression in hyperosmolar state (500 mOsm), which was suppressed by blocking IL6. The inverse pattern of Bcl-2 expression related to IL6 and hyperosmolarity was also revealed. These suggested that JAKSTAT signaling pathway of apoptosis was associated with IL6.

In this study, blocking IL6 inhibited the apoptosis of conjunctival epithelial cells under hyperosmolar condition, and the process was associated with the JAK-STAT signal pathway (Figure 4). This indicated that IL6 could be one of the important cytokines affecting the pathogenesis of dry eye. Therefore, in dry eye patients, IL6 could be a biologic marker, and regulating IL6 though the IL6/JAK/STAT3 signaling pathway could be an effective therapeutic target.

\section{Conclusion}

Hyperosmolarity induced apoptosis in conjunctival epithelial cells was suppressed by blocking IL6, which suggests that IL6 
may play an important role in the pathogenesis of dry eye disease.

\section{Competing Interests}

The authors declare that there is no conflict of interests regarding the publication of this paper.

\section{References}

[1] C. Baudouin, P. Aragona, E. M. Messmer et al., "Role of hyperosmolarity in the pathogenesis and management of dry eye disease: proceedings of the OCEAN group meeting," The Ocular Surface, vol. 11, no. 4, pp. 246-258, 2013.

[2] J. P. Gilbard, J. B. Carter, D. N. Sang, M. F. Refojo, L. A. Hanninen, and K. R. Kenyon, "Morphologic effect of hyperosmolarity on rabbit corneal epithelium," Ophthalmology, vol. 91, no. 10, pp. 1205-1212, 1984.

[3] J. P. Gilbard, S. R. Rossi, K. L. Gray, L. A. Hanninen, and K. R. Kenyon, "Tear film osmolarity and ocular surface disease in two rabbit models for keratoconjunctivitis sicca," Investigative Ophthalmology \& Visual Science, vol. 29, no. 3, pp. 374-378, 1988.

[4] J. P. Gilbard, S. R. Rossi, K. L. Gray, and L. A. Hanninen, "Natural history of disease in a rabbit model for keratoconjunctivitis sicca," Acta Ophthalmologica, vol. 67, supplement 192, pp. 95101, 1989.

[5] S. C. Pflugfelder, S. C. G. Tseng, K. Yoshino, D. Monroy, C. Felix, and B. L. Reis, "Correlation of goblet cell density and mucosal epithelial membrane mucin expression with rose bengal staining in patients with ocular irritation," Ophthalmology, vol. 104, no. 2, pp. 223-235, 1997.

[6] I. K. Gipson and T. Inatomi, "Cellular origin of mucins of the ocular surface tear film," Advances in Experimental Medicine and Biology, vol. 438, pp. 221-227, 1998.

[7] W.-L. Fei, J.-Q. Chen, X. Du et al., "Dry eye in graft-versus-host disease," Chinese Journal of Ophthalmology, vol. 39, no. 11, pp. 686-690, 2003.

[8] Y. Ogawa, S. Okamoto, M. Wakui et al., "Dry eye after haematopoietic stem cell transplantation," British Journal of Ophthalmology, vol. 83, no. 10, pp. 1125-1130, 1999.

[9] T. Igarashi, C. Fujimoto, H. Suzuki et al., "Short-time exposure of hyperosmolarity triggers interleukin- 6 expression in corneal epithelial cells," Cornea, vol. 33, no. 12, pp. 1342-1347, 2014.

[10] M. A. Lemp, C. Baudouin, J. Baum et al., "The definition and classification of dry eye disease: report of the definition and classification subcommittee of the international Dry Eye WorkShop (2007)," The Ocular Surface, vol. 5, no. 2, pp. 75-92, 2007.

[11] K.-C. Yoon, I.-Y. Jeong, Y.-G. Park, and S.-Y. Yang, "Interleukin6 and tumor necrosis factor- $\alpha$ levels in tears of patients with dry eye syndrome," Cornea, vol. 26, no. 4, pp. 431-437, 2007.

[12] K. Turner, S. C. Pflugfelder, Z. Ji, W. J. Feuer, M. Stern, and B. L. Reis, "Interleukin-6 levels in the conjunctival epithelium of patients with dry eye disease treated with cyclosporine ophthalmic emulsion," Cornea, vol. 19, no. 4, pp. 492-496, 2000.

[13] Y. Liu, P.-K. Li, C. Li, and J. Lin, "Inhibition of STAT3 signaling blocks the anti-apoptotic activity of IL-6 in human liver cancer cells," The Journal of Biological Chemistry, vol. 285, no. 35, pp. 27429-27439, 2010.
[14] I. A. Valsero, L. S. Romaní, L. G. Posadas, A. L. García, and Y. Diebold, "IL-6 as a corneal wound healing mediator in an invitro scratch assay," Experimental Eye Research, vol. 125, pp. 183-192, 2014.

[15] G.-X. Jiang, X.-Y. Zhong, Y.-F. Cui et al., "IL-6/STAT3/TFF3 signaling regulates human biliary epithelial cell migration and wound healing in vitro," Molecular Biology Reports, vol. 37, no. 8, pp. 3813-3818, 2010.

[16] T. Sakimoto, S. Sugaya, A. Ishimori, and M. Sawa, "Antiinflammatory effect of IL-6 receptor blockade in corneal alkali burn," Experimental Eye Research, vol. 97, no. 1, pp. 98-104, 2012.

[17] Z.-Q. Lin, T. Kondo, Y. Ishida, T. Takayasu, and N. Mukaida, "Essential involvement of IL-6 in the skin wound-healing process as evidenced by delayed wound healing in IL-6-deficient mice," Journal of Leukocyte Biology, vol. 73, no. 6, pp. 713-721, 2003.

[18] L. Luo, D.-Q. Li, and S. C. Pflugfelder, "Hyperosmolarityinduced apoptosis in human corneal epithelial cells is mediated by cytochrome c and MAPK pathways," Cornea, vol. 26, no. 4, pp. 452-460, 2007.

[19] S. C. Pflugfelder, D. Jones, Z. Ji, A. Afonso, and D. Monroy, "Altered cytokine balance in the tear fluid and conjunctiva of patients with Sjogren's syndrome keratoconjunctivitis sicca," Current Eye Research, vol. 19, no. 3, pp. 201-211, 1999.

[20] A. Solomon, D. Dursun, Z. Liu, Y. Xie, A. Macri, and S. C. Pflugfelder, "Pro- and anti-inflammatory forms of interleukin1 in the tear fluid and conjunctiva of patients with dry-eye disease," Investigative Ophthalmology and Visual Science, vol. 42, no. 10, pp. 2283-2292, 2001.

[21] D. T. Jones, D. Monroy, Z. Ji, S. S. Atherton, and S. C. Pflugfelder, "Sjogren's syndrome: cytokine and Epstein-Barr viral gene expression within the conjunctival epithelium," Investigative Ophthalmology \& Visual Science, vol. 35, no. 9, pp. 3493-3504, 1994.

[22] J. Zhang, X. Yan, and H. Li, "Analysis of the correlations of mucins, inflammatory markers, and clinical tests in dry eye," Cornea, vol. 32, no. 7, pp. 928-932, 2013.

[23] D. Hebenstreit, J. Horejs-Hoeck, and A. Duschl, "JAK/STATdependent gene regulation by cytokines," Drug News and Perspectives, vol. 18, no. 4, pp. 243-249, 2005.

[24] R. J. Stefan, "Il-6 trans-signaling via the soluble IL-6 receptor: importance for the proinflammatory activities of IL-6," International Journal of Biological Sciences, vol. 8, no. 9, pp. 1237-1247, 2012.

[25] A. J. Brooks, W. Dai, M. L. O’Mara et al., "Mechanism of activation of protein kinase JAK2 by the growth hormone receptor," Science, vol. 344, no. 6185, Article ID 1249783, 2014.

[26] J. S. Rawlings, K. M. Rosler, and D. A. Harrison, "The JAK/STAT signaling pathway," Cell Science, vol. 117, pp. 1280-1283, 2004.

[27] S. C. Afford, J. Pongracz, R. A. Stockley, J. Crocker, and D. Burnett, "The induction by human interleukin-6 of apoptosis in the promonocytic cell line U937 and human neutrophils," The Journal of Biological Chemistry, vol. 267, no. 30, pp. 21612-21616, 1992. 


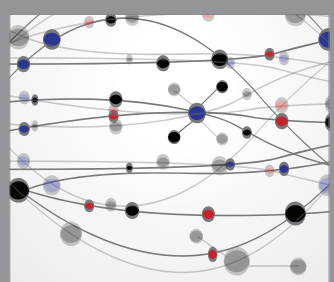

The Scientific World Journal
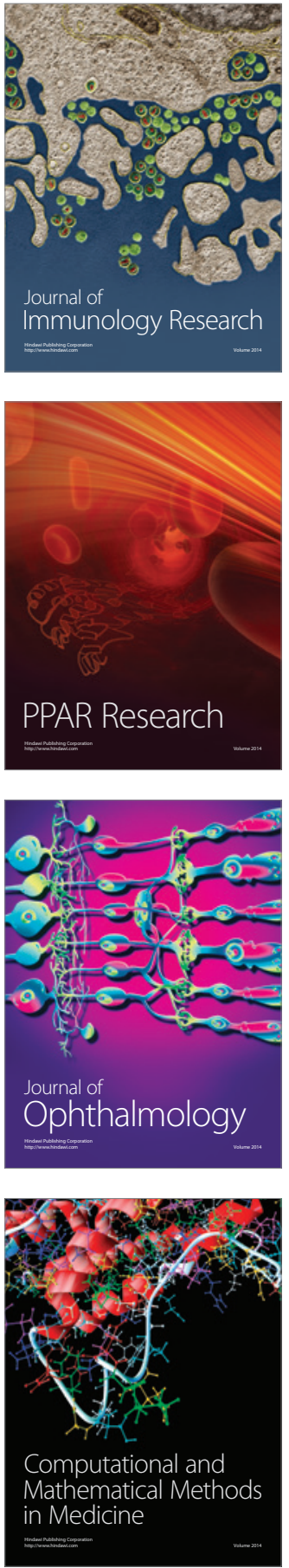

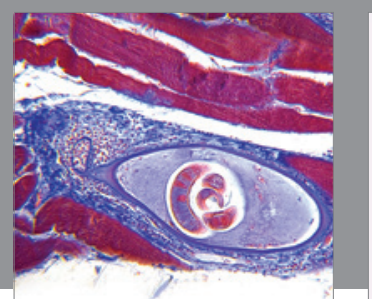

Gastroenterology Research and Practice

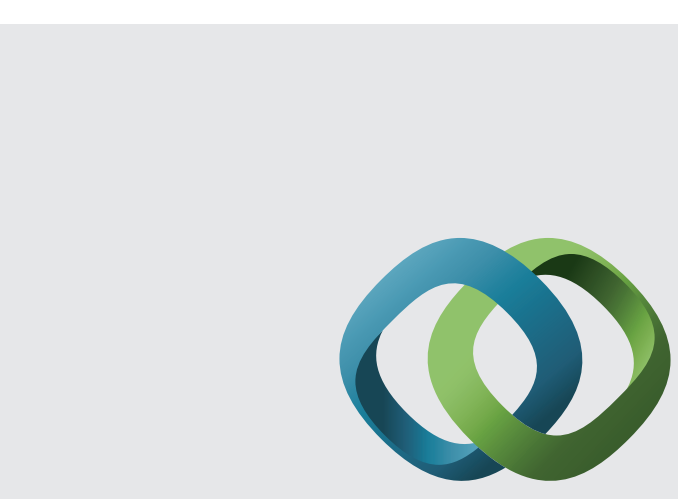

\section{Hindawi}

Submit your manuscripts at

http://www.hindawi.com
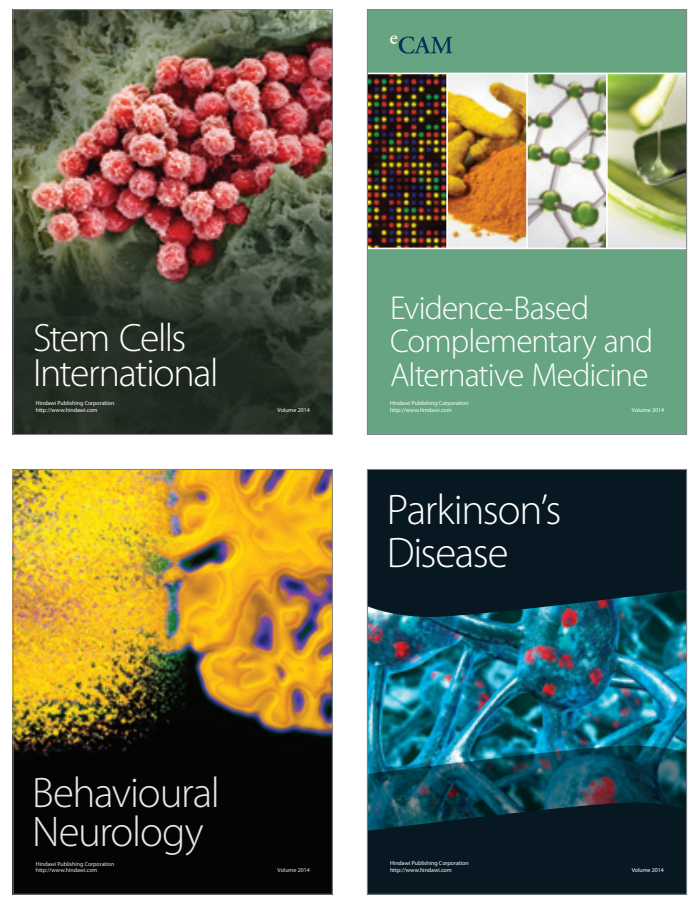
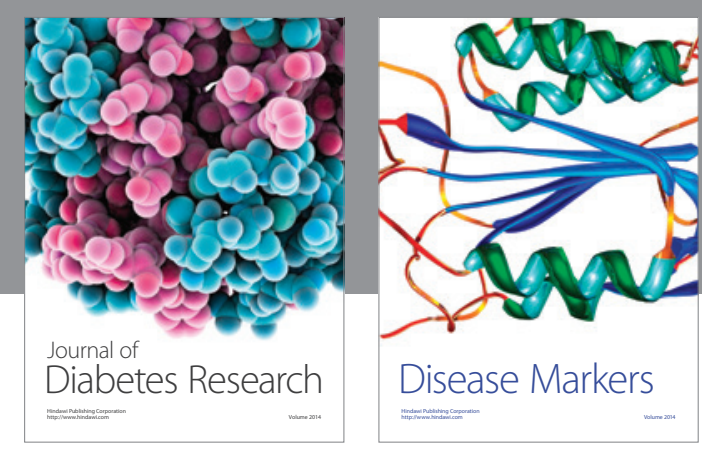

Disease Markers
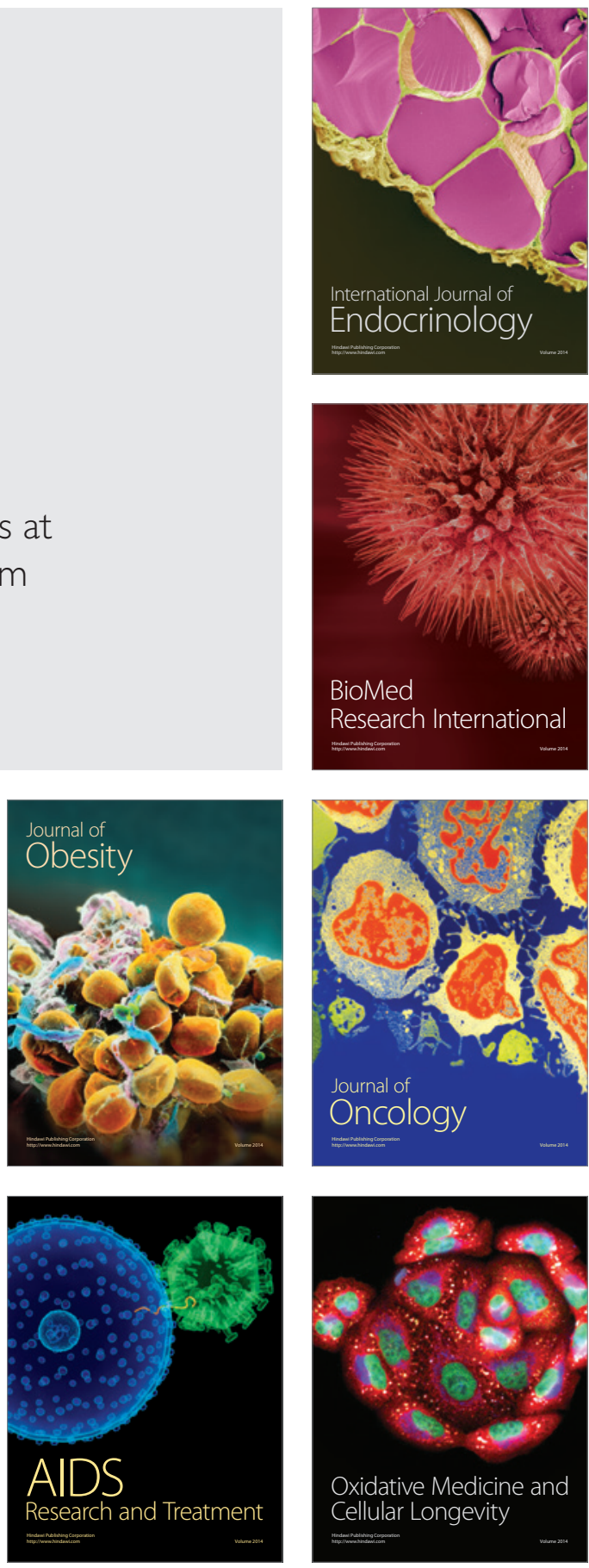